\title{
Antecedents of Knowledge Management Practices: Case of Malaysian Practitioners
}

\author{
Mohamed Jalaldeen Mohamed Razi*, Mohd Izzuddin Mohd Tamrin, Abdul Rahman Ahmad Dahlan, \\ Noor Azian Mohamad Ali \\ Department of Information Systems, International Islamic University Malaysia, Kuala Lumpur, Malaysia
}

\begin{tabular}{l}
\hline \hline Article Info \\
\hline Article history: \\
Received Nov 24, 2017 \\
Revised Jan 25, 2018 \\
Accepted Feb 08, 2018 \\
\hline
\end{tabular}

Keywords:

KM behavior

SECI

SmartPLS

TPB

TRA

\begin{abstract}
In this paper, we investigated the knowledge management (KM) behavior of executives in Malaysia who work in different sectors and involved in Information Technology (IT) related fields. We proposed a conceptual framework based on the Theory of Reasoned Action (TRA), the Theory of Planned Behavior (TPB) and Unified Theory of Acceptance and Use of Technology (UTAUT) to study their intention and involvement in KM initiatives. The knowledge creation theory (SECI process) was employed to operationalize KM intention and KM behavior. We proposed six independent variables that represent the social-cultural nature of $\mathrm{KM}$ as the antecedence of KM intention. These variables are trust, management support, decentralization, IT support, performance expectancy (PE), and effort expectancy (EE). Seventy-four executives from both private and government-linked organizations responded to our online questionnaire. SmartPLS3 was used to run the analysis. The reliability was ensured with the factor loadings, Cronbach's alpha, Composite Reliability (CR) that met the fit requirement of above $0.6,0.7$ and 0.7 respectively. The convergent validity was confirmed through average variance extracted (AVE) that met the fit requirement of above 0.5 . The discriminant validity was assessed by using Fornell and Larcker's criterion. Finally, the structural model confirmed that only PE of KM, and EE of KM are the significant predictors of KM intention and the $\mathrm{KM}$ intention significantly predicts $\mathrm{KM}$ behavior. The implications of the findings are discussed in detail at the end of the paper.
\end{abstract}

Copyright (C) 2018 Institute of Advanced Engineering and Science. All rights reserved.

Corresponding Author:

Mohamed Jalaldeen Mohamed Razi, Department of Information Systems, Kulliyyah of Information and Communication Technology, International Islamic University Malaysia, P.O Box 10, 53100, Kuala Lumpur, Malaysia.

Email: razimjm@iium.edu.my

\section{INTRODUCTION}

Access to the modern business enablers such as access to modern technology infrastructure, access to vast available information, and access to the global market are common to everyone, thus cannot depend on those factors for competitive advantage anymore. The only unique competitive force in the modern world is the knowledge an organization possesses, creates, store, disseminate, and apply in their day to day operations. Therefore, the modern business organizations are more keen to know how can they make the employees, especially the knowledge workers, to involve in the knowledge management (KM) processes. As a result, currently, the academic researchers and the corporate top-level managers are giving more attention to studying the different facets of KM.

Accordingly, wide-ranging attempts have been taken to study the antecedence of KM practices in the recent past including in the IT-related sectors. However, most of them concentrated only on knowledge 
sharing (KS) behavior. For example, Ghobadi [1] has done an extensive review of around 50 articles, which were published between 1993 to 2011, that focused on KS drivers in software teams. Similarly, Mueller [2] has investigated the cultural antecedence of KS. Nevertheless, there are studies that concentrate on KM including knowledge creation (KC) \& KS as well; for example, [3-8]. However, none of these studies operationalized the KM from its root processes of SECI (socialization, externalization, combination, internalization) which is proposed in the knowledge creation theory [9]. Indeed, there is a study [10] based on SECI, but it is limited only to KM intention. Other than this work it is very difficult to find a study on antecedence of KM behavior based on it root processes of SECI. To bridge this gap, the current study investigates the antecedence of KM intention and $\mathrm{KM}$ behavior by operationalizing KM through SECI process. For this purpose, a conceptual research framework with a hypothetical research model was formulated based on Theory of Reasoned Action (TRA) [11] and Theory of Planned Behavior (TPB) [12] which advocates human behavior is influenced by human intention. To empirically test the research model, data were collected from 74 executive level employees who are involved in Information Technology (IT) related qualifications and works in private and government link corporations in Malaysia. It is believed that the findings of this study will provide an in-depth understanding on the antecedence of KM behavior among the executives, especially in the IT sector, which would be the interest of corporate executives who aspire to see KM culture prevail in their respective organizations. The academic researchers, of course, also would be interested to know the outcome of the new approach.

The next section elaborates the conceptual framework used in this study while section 3 briefly describe the methodology used in this study. Section 4 presents the results with a detailed discussion on findings. The final section tries to derive a conclusion.

\section{CONCEPTUAL FRAMEWORK}

TRA [11] and TPB [12], which suggest that behavioral intention leads to human behavior, were considered as the supporting theories to the proposed research framework. The SECI (socialization, externalization, combination, and internalization) processes, the outcome of knowledge creation theory [13], laid the operationalization of KM behavior as SECI processes represent both knowledge creation and sharing behavior [14]-[16]. Thus, involvement in KM behavior could be measured by the involvement in SECI processes.

The socialization process refers to the conversion of tacit knowledge to new tacit knowledge through social interactions and shared experience among organizational members [17] while externalization means the expression of tacit knowledge and its conversion into comprehensible forms that are easier to understand [18]. Similarly, the combination process collects explicit knowledge from inside or outside the organization and then combined, edited, or processed to form more complex and systematic explicit knowledge and the internalization can be understood as praxis, where knowledge is applied and used in practical situations and becomes the base for new routines [19].

The antecedence of KM intention and KM behavior were operationalized referring unified theory of acceptance and use of technology (UTAUT) [20] and few prominent previous related works [14, 20-23]. Consequently, trust among colleagues, top management support, decentralization of decision-making process, and availability of IT support are considered as the antecedence of KM behavior denoting the elements of organizational climate. Meantime to symbolize the individual acceptance, performance expectancy of KM (PE of KM) and effort expectancy of KM (EE of KM) which are derived from UTAUT were incorporated.

Trust refers to the degree of reciprocal faith among the colleagues in terms of intention and behavior within the organization [21]. People are more willing to participate in knowledge exchange when their relationships are high in trust, and the increase in knowledge exchange brought by mutual trust results in knowledge creation [14]. The positive relationship between trust and KM has been established in recent works [24], [25]. Therefore, we propose

H1: Trust will positively influence KM intention

Management support means the degree of support from top managers for KM through providing guidance and necessary resources [22]. Without top management's commitment and active leadership role in $\mathrm{KM}$ activities, it is cumbersome to implement KM successfully [5]. The effect of management support and KM oriented leadership towards KM initiatives has been explained [3], [26], as such, we believe

H2: Management Support will positively influence KM intention

Decentralization refers to a management structure that emphasizes employee autonomy and participation in decision making [23]. Centralized structure hinders interdepartmental communication and frequent sharing of ideas because it imposes certain time-consuming communication channels which causes distortion and discontinuousness of ideas [27] and hamper the KM process [14]. The positive effects of 
decentralization on KM activities have been well documented [28], [29]. Therefore, we have no reason to think negatively about the following hypothesis.

H3: Decentralization will positively influence KM intention

IT Support denotes to the degree of availability of IT support for KM process initiatives within the organization [14]. IT is a critical enabler when implementing KM [30] because IT can enable rapid search, access, and retrieval of information [31]. The relationship of IT and KM behavior well explained [15, 32]. Therefore, we propose

H4: IT Support will positively influence KM intention

Performance Expectancy (PE) of KM means the degree to which an individual believes that involvement in KM processes will help him/her to attain gains in job performance [20]. The works of [33, 34] suggest the following relationship.

H5: PE of KM will positively influence KM intention

Effort Expectancy (EE) of KM explains the degree of ease associated with the involvement in KM process [20]. The influence of effort expectancy on behavior is obvious [20], [35]

H6: EE of KM will positively influence KM intention

$\mathrm{KM}$ intention means the degree of perceived intention to be involved in the KM process ( $\mathrm{KC} \& \mathrm{KS})$ by the organizational individuals within the prevailing organizational context [36] while KM behavior refers to the real involvement in the KM process $(\mathrm{KC} \& \mathrm{KS})$ by the organizational individuals within the prevailing organizational context [36]. Based on TRA [11] and TPB [12] the following hypothesis was formulated.

$\mathrm{H} 7$ : KM intention will positively influence $\mathrm{KM}$ behavior

To show the above hypothetical relationships, a research model was developed as shown in Figure 1.

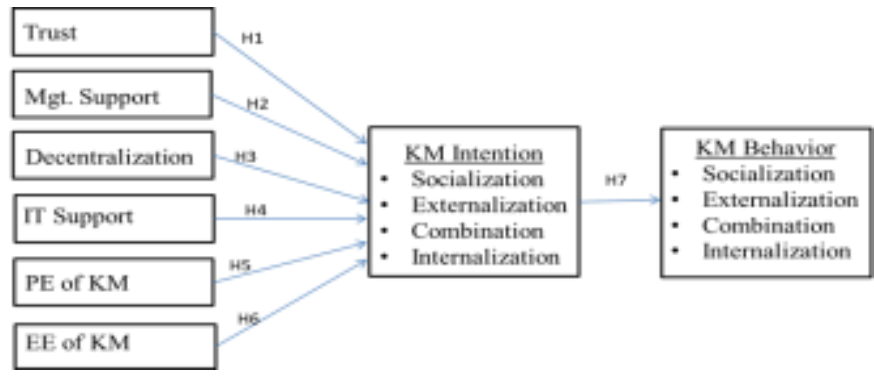

Figure 1. Proposed research model

\section{RESEARCH METHOD}

A self-administered online questionnaire was used to collect data from 74 different levels of executives who are working in the IT sector of private and government link corporations in Malaysia. The questionnaire items were adapted from previous studies [14], [20]-[23]. Respondents were asked to indicate (on a 7-point Likert scale ranging from "strongly disagree" to "strongly agree") their level of agreements on statements. SmartPLS3 was used for measurement model analysis and structural model analysis. The measurement model was evaluated using internal consistency reliability, indicator reliability, convergent reliability and discriminant validity. The coefficient of determination $\left(\mathrm{R}^{2}\right)$ and path coefficients was evaluated in structural model assessment.

\section{RESULTS AND ANALYSIS}

The measurement model as shown in Figure 2. 


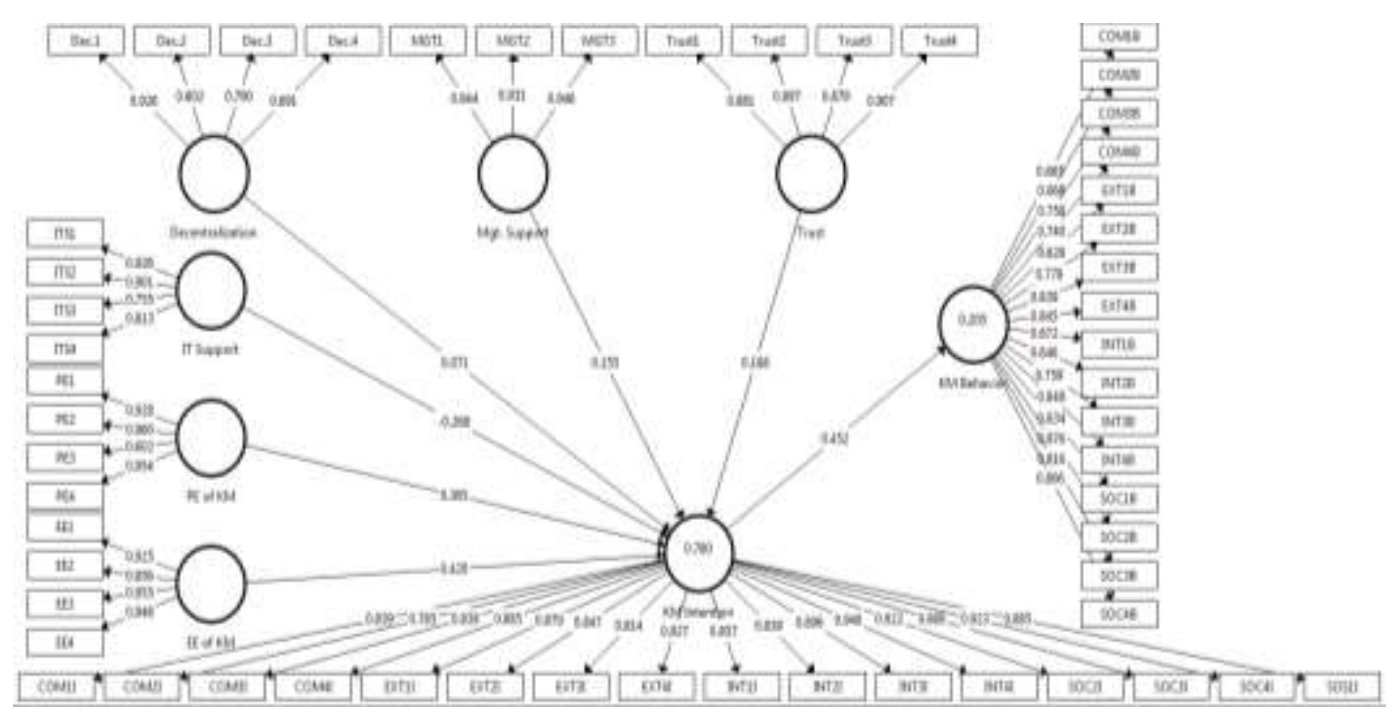

Figure 2. Measurement model

Table 1 shows the factor loading values of each item, and Cronbach's Alpha $(\alpha)$, Composite Reliability (CR), and Average Variance Extracted (AVE) values for each variable. Following [37], 0.65 was considered as the threshold value for factor loadings and all items met the criteria. The Cronbach's Alpha and CR values are greater than the threshold value of 0.7 and the AVE values are greater than the threshold value of 0.5 . Therefore, the reliability and convergent validity of the instruments used are confirmed.

Table 1. Factor Loadings, Cronbach's Alpha, Composite Reliability, Average Variance Extracted

\begin{tabular}{|c|c|c|c|c|}
\hline Variable & Loadings & $\alpha$ & $\mathrm{CR}$ & AVE \\
\hline \multicolumn{2}{|l|}{ Trust } & 0.914 & 0.939 & 0.794 \\
\hline \multicolumn{5}{|l|}{ Trust1, Trust2, Trust3, Trust 4} \\
\hline \multirow{2}{*}{\multicolumn{5}{|c|}{ Mgt. Supt. }} \\
\hline & $0.944,0.931,0.946$ & & & \\
\hline \multicolumn{5}{|l|}{ Decentralization } \\
\hline \multicolumn{5}{|l|}{ Dec.1, Dec.2, Dec.3, Dec.4 } \\
\hline \multicolumn{5}{|l|}{ IT Supt. } \\
\hline \multicolumn{5}{|l|}{ ITS1, ITS2, } \\
\hline \multicolumn{5}{|l|}{ PE of KM } \\
\hline PE1, PE2, PE3, PE4 & $0.928,0.960,0.602,0.954$ & & & \\
\hline \multicolumn{4}{|l|}{$\mathrm{EE}$ of $\mathrm{KM}$} & 0.850 \\
\hline \multirow{2}{*}{\multicolumn{2}{|c|}{$\begin{array}{l}\text { EE 1, EE } 2, \text { EE } 5, \text { EE4 } \\
\text { KM Intention }\end{array}$}} & & & \\
\hline & & 0.979 & 0.981 & 0.763 \\
\hline SOC1I, SOC2I, SOC3I, SOC4I & $0.885,0.922,0.880,0.923$ & & & \\
\hline EXT1I, EXT2I, EXT3I, EXT4I & $0.879,0.847,0.814,0.927$ & & & \\
\hline COM1I, COM2I, COM3I, COM4I & $0.839,0.785,0.838,0.885$ & & & \\
\hline INT1I, INT2I, INT3I, INT4I & $0.857,0.839,0.896,0.940$ & & & \\
\hline \multicolumn{2}{|l|}{ KM Behavior } & 0.958 & 0.960 & 0.604 \\
\hline & $0.834,0.876,0.816,0.806$ & & & \\
\hline \multicolumn{5}{|l|}{ EXT1B, EXT2B, EXT3B, EXT4B } \\
\hline \multirow{2}{*}{$\begin{array}{l}\text { COM1B, COM2B, COM3B, } \\
\text { COM4B }\end{array}$} & $0.665,0.668,0.758,0.740$ & & & \\
\hline & $0.672,0.646,0.759,0.848$ & & & \\
\hline INT1B, INT2B, INT3B, INT4B & & & & \\
\hline
\end{tabular}

The discriminant validity was assessed by using Fornell and Larcker's criterion. The correlations and discriminant validity are shown in Table 2. The square root of AVE should exceed the correlations between the measure and all the other measures, and the indicators' loadings are higher against their respective construct compared to the other constructs. Accordingly, all variables satisfy the requirements. Therefore, the researchers of this study believe that the study had proven that all the reliability and validity tests conducted for the measurement model had achieved the satisfactory level. 
Table 2. Discriminant Validity

\begin{tabular}{lcccccccc}
\hline \multicolumn{1}{c}{0} & Decentralization & $\begin{array}{c}\text { EEof } \\
\text { KM }\end{array}$ & $\begin{array}{c}\text { IT } \\
\text { Support }\end{array}$ & $\begin{array}{c}\text { KM } \\
\text { Behavior }\end{array}$ & $\begin{array}{c}\text { KM } \\
\text { Intention }\end{array}$ & $\begin{array}{c}\text { Mgt. } \\
\text { Support }\end{array}$ & $\begin{array}{c}\text { PEof } \\
\text { KM }\end{array}$ & $\begin{array}{c}\text { Trust } \\
\text { Decentralization }\end{array}$ \\
EE of KM & $\mathbf{0 . 8 0 7}$ & & & & & & & \\
IT Support & 0.458 & $\mathbf{0 . 9 2 2}$ & & & & & & \\
KM Behavior & 0.574 & 0.594 & $\mathbf{0 . 8 5 1}$ & & & & & \\
KM Intention & 0.645 & 0.541 & 0.630 & $\mathbf{0 . 7 7 7}$ & & & \\
Mgt. Support & 0.446 & 0.814 & 0.433 & 0.452 & $\mathbf{0 . 8 7 3}$ & & & \\
PE of KM & 0.571 & 0.567 & 0.655 & 0.499 & 0.630 & $\mathbf{0 . 9 4 0}$ & \\
Trust & 0.445 & 0.888 & 0.633 & 0.577 & 0.830 & 0.694 & $\mathbf{0 . 8 7 4}$ & $\mathbf{0 . 8 9 1}$ \\
\hline
\end{tabular}

Having established the validity and the reliability of the measurement model, to test the hypothesized relationship, bootstrapping (with 500 sub-samples) was performed using SmartPLS 3.0. The predictive relevance of the model, i.e. the quality of the structural model, was assessed by R2. This depicts the variance in the endogenous variables of $\mathrm{KM}$ intention and $\mathrm{KM}$ behavior. Based on the result reported in Figure 2, R2 was found to be 0.780 and 0.205 for KM intention and KM behavior respectively. Using the assessment criterion suggested by [38], we concluded that it is significant. All the hypotheses were tested by examining the significance of the respective path coefficients. The results are shown in figure 3 and the summary of the results are shown in Table 3.

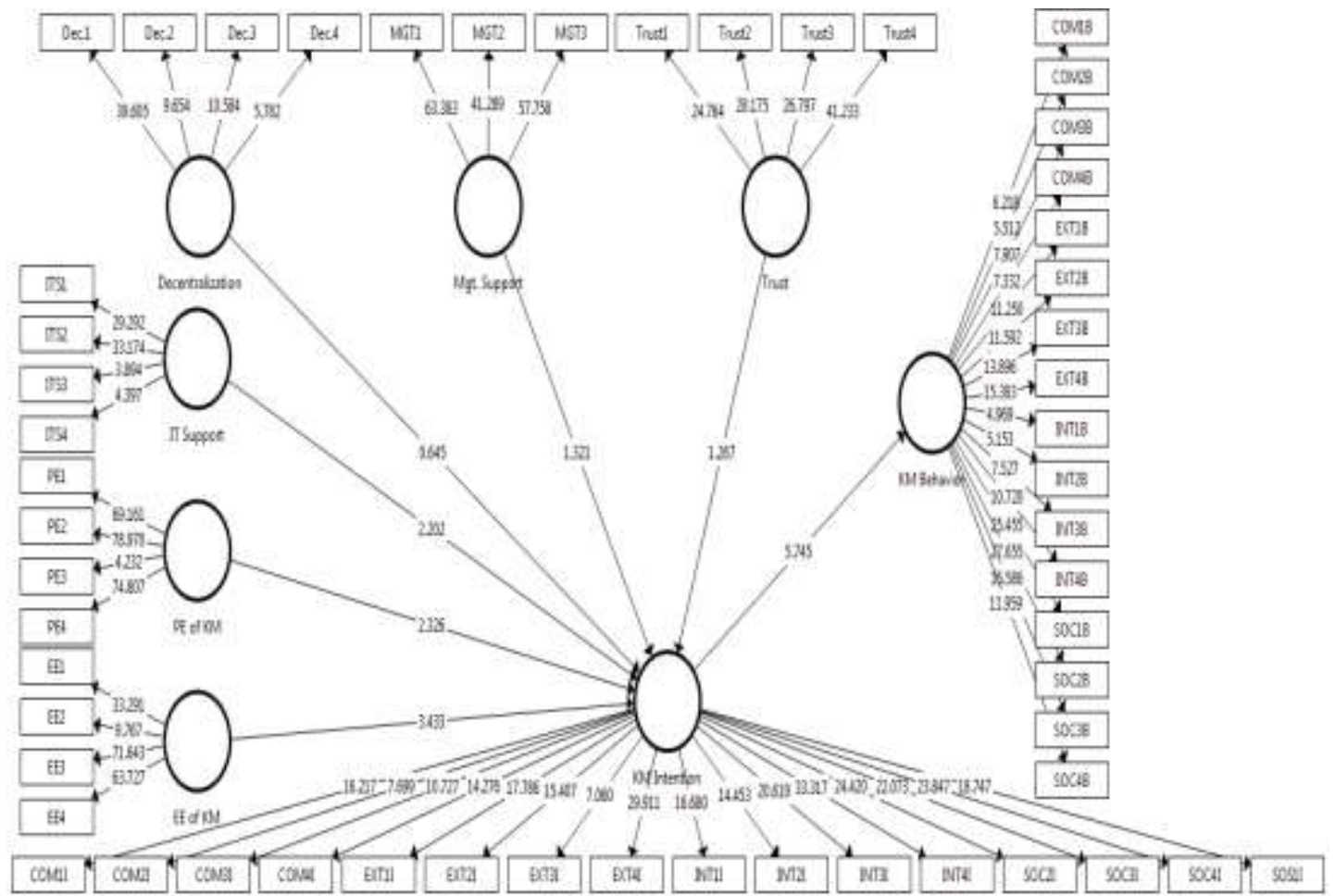

Figure 3. Structural model

Table 3. Result Summary

\begin{tabular}{lcccc}
\hline \multicolumn{1}{c}{ Hypotheses } & $\beta$ & $\mathrm{t}$ & $\mathrm{p}$ & \\
\hline H1 Trust -> KM Intention & 0.168 & 1.267 & 0.206 & Not Supported \\
H2 Mgt. Support -> KM Intention & 0.155 & 1.321 & 0.187 & Not Supported \\
H3 Decentralization -> KM Intention & 0.071 & 0.645 & 0.519 & Not Supported \\
H4 IT Support -> KM Intention & -0.268 & 2.202 & 0.028 & Not Supported \\
H5 PE of KM -> KM Intention & 0.365 & 2.326 & 0.020 & Supported \\
H6 EE of KM -> KM Intention & 0.420 & 3.433 & 0.001 & Supported \\
H7 KM Intention -> KM Behavior & 0.452 & 5.745 & 0.000 & Supported \\
\hline
\end{tabular}


Out of the seven hypotheses proposed three are supported. PE of KM (H5) and EE of KM (H6) are positively influenced KM intention with positive path coefficient $(\beta)$ with significant $t$ value at 0.001 and 0.05 confidence level respectively. Even though it was expected that IT support will have a positive influence on KM intention, the result showed a negative $\beta(-0.268)$ value with significant $\mathrm{t}$ value $(\mathrm{t}=2.202, \mathrm{p}=0.028)$. Therefore, the said hypothesis was considered not supported. The other three hypotheses $(\mathrm{H} 1, \mathrm{H} 2$, and H3) were also considered not supported as the $\mathrm{p}$ values are greater than 0.05 .

As a summary, the findings of this study only recognizes the positive relationship of factors of individual acceptance which are derived from UTAUT; performance expectancy of KM $(b=0.365, t=2.326$, $\mathrm{p}=0.020)$ and effort expectancy of $\mathrm{KM}(\mathrm{b}=0.420, \mathrm{t}=3.433, \mathrm{p}=0.001)$ on $\mathrm{KM}$ intention. The results suggest that the more respondents perceive that KM is useful in doing the job, lead to better pay and improves their productivity; the more likely they are to be involved in KM. Similarly, the more they perceive that involving in $\mathrm{KM}$ processes is easy, clear to understand and easy to learn; the more likely they are to be involved in KM. Theoretically, these result further strengthens the propositions of UTAUT [20] in predicting individual behavioral intention and the current findings are consistent with many previous research works [33], [34], [39]-[42].

The scale used for measuring performance expectancy focused on involvement in KM useful in accomplishing job task, enhance productivity and leads to better pay. Therefore, from the practical point of view, the managers could make an environment where the executives believe that if they involve in KM it would lead to increase in their performance. Perhaps they could make an awareness of how the involvement in KM process will improve their performance and their productivity. At the same time, the managers could make it clear how the involvement in KM can lead to better pay; i.e. salary increment, bonus or promotion.

The items used for measuring effort expectancy focused on the degree of ease in involving in KM. The scales used to measure effort expectancy focused on easy to learn, easy to be involved and clear to understand the role in the KM process. Therefore, the corporate managers may emphasize or educate the easiness of involving in $\mathrm{KM}$ and make clear the role expected from each of them for KM initiatives which are being introduced in their particular organization.

The findings also confirm the positive influence of KM Intention towards KM Behavior $(b=0.452$, $\mathrm{t}=5.745, \mathrm{p}=0.000)$ that strength the fundamental proposition of TRA [11] and TPB [12]. However, the other four hypotheses $(\mathrm{H} 1, \mathrm{H} 2, \mathrm{H} 3, \mathrm{H} 4)$ were not supported contradicting to the literature cited in the hypotheses formulation section. The respondents, the executives in the IT field with at least a university bachelor degree in ICT, are considered knowledge workers. Knowledge workers tend to be autonomous, self-motivated and self-reliance. Thus, they may not be expecting the trust culture (H1), management support (H2) and decentralized structure (H3) as very important or influencing factors them to be involved in KM behavior. They are naturally inclined to be involved in such activities regardless of organizational climate. It is quite difficult to understand why the IT support has a negative coefficient of -0.268 which literally means an inverse relationship between IT support and KM intention and KM behavior. The respondents might have misinterpreted the questionnaire items as the questions are focused on IT support for communication and collaboration. For example, a question focuses on IT support for collaborative works regardless of time and place; another question focuses on IT support for communication among colleagues; next question focuses on IT support for searching necessary information and sharing and so on. As the respondents are IT experts and they use the IT in a wider range of capacity to get the optimum from it, they might have perceived the mere use of IT for communication and collaboration might be hindering their work activities and performance.

\section{CONCLUSION}

The current study provides theoretical and practical understandings on antecedence of KM intention and $\mathrm{KM}$ behavior among practitioners in the corporate sector. The findings should be beneficial to both researchers in the domain of KM and the practitioners; the decision makers in the corporate sector. For the researchers, the conceptual research framework used in this study can be used to test the other settings involving different types of population and sample. For the managers, the findings of this study propose that if they really interested to see their executives, especially who involve in IT related works, involved in KM practices, they have to inform them about the usefulness of $\mathrm{KM}$ to better perform in their job and involvement in $\mathrm{KM}$ is easy and comfortable.

Similar to most of the research work, there are limitations related to the conduct of this study as well. The respondents are limited to one particular type. Future works may consider extending the scope of the population by considering a wider range of populations. Moreover, in addition to the six antecedence considered in this study, some more variables such as motivational factors, cultural factors, structural factors etc. could be examined in future works. 


\section{ACKNOWLEDGEMENTS}

This work has been supported through International Islamic University Malaysia Research Initiative Grant Scheme (RIGS16-148-0312).

\section{REFERENCES}

[1] S. Ghobadi, "What drives knowledge sharing in software development teams: A literature review and classification framework," Information \& Management, vol. 52, no. 1, pp. 82-97, 2015.

[2] J. Mueller, "A specific knowledge culture: Cultural antecedents for knowledge sharing between project teams," European Management Journal, vol. 32, no. 2, pp. 190-202, 2014.

[3] M. J. Donate and J. D. S. de Pablo, "The role of knowledge-oriented leadership in knowledge management practices and innovation," Journal of Business Research, vol. 68, no. 2, pp. 360-370, 2015.

[4] D. Holt, S. Bartczak, S. Clark, and M. Trent, "The development of an instrument to measure readiness for knowledge management," Knowledge Management Research \& Practice, vol. 5, no. 2, pp. 75-92, 2007.

[5] C. Wei, C. Choy, and W. Yew, "Is the Malaysian telecommunication industry ready for knowledge management implementation?," Journal of Knowledge Management, vol. 13, no. 1, pp. 69-87, 2009.

[6] W. Taylor and M. Schellenberg, "Measuring organizational readiness for knowledge management," Advanced Topics in Information Resources Management: Volume 4, vol. 4, p. 93, 2005.

[7] N. D. Mamaghani, R. Samizadeh, and F. Saghafi, "Evaluating the readiness of Iranian research centers in knowledge management," American Journal of Economics and Business Administration, vol. 3, no. 1, p. 203, 2011.

[8] A. Shirazi and S. Mortazavi, "Factors affecting employees' readiness for knowledge management," European Journal of Economics, Finance and Administrative Sciences, vol. 7, 2011.

[9] I. Nonaka, "Organizational knowledge creation theory: a first comprehensive test," International Business Review, vol. 3, no. 4, pp. 337-351, 1994.

[10] N. S. A. Karim, M. J. M. Razi, N. Mohamed, and L. M. Abdullah, "Influential Factors of KM Process Adoption: A Social-technological Based Approach," International Journal of Innovation and Business Strategy, vol. 01, no. December, pp. 95-102, 2012.

[11] M. Fishbein and I. Ajzen, Belief, attitude, intention and behaviour: An introduction to theory and research. Addison-Wesley, 1975.

[12] I. Ajzen, "The theory of planned behavior," Organizational behavior and human decision processes, vol. 50, no. 2, pp. 179-211, 1991.

[13] I. Nonaka, P. Byosiere, C. C. Borucki, and N. Konno, "Organizational knowledge creation theory: a first comprehensive test," International Business Review, vol. 3, no. 4, pp. 337-351, 1994.

[14] H. Lee and B. Choi, "Knowledge management enablers, processes, and organizational performance: An integrative view and empirical examination," Journal of management information systems, vol. 20, no. 1, pp. 179228, 2003.

[15] W. Teerajetgul and C. Charoenngam, "Factors inducing knowledge creation: empirical evidence from Thai construction projects," Engineering, Construction and Architectural Management, vol. 13, no. 6, pp. 584-599, 2006.

[16] I. Becerra-Fernandez, A. Gonzalez, and R. Sabherwal, Knowledge Management: Challenges (Solutions and Technologies. Pearson/Prentice Hall). 2004.

[17] M. Alavi and D. E. Leidner, "Review: Knowledge management and knowledge management systems: Conceptual foundations and research issues," MIS quarterly, pp. 107-136, 2001.

[18] I. Becerra-Fernandez and R. Sabherwal, "Organizational knowledge management: A contingency perspective," Journal of management information systems, vol. 18, no. 1, pp. 23-55, 2001.

[19] I. Nonaka and R. Toyama, "The knowledge-creating theory revisited: knowledge creation as a synthesizing process," Knowledge Management Research \&\# 38; Practice, vol. 1, no. 1, pp. 2-10, 2003.

[20] V. Venkatesh, M. G. Morris, G. B. Davis, and F. D. Davis, "User acceptance of information technology: Toward a unified view," MIS quarterly, pp. 425-478, 2003.

[21] S. Y. Choi, Y. S. Kang, and H. Lee, "The effects of socio-technical enablers on knowledge sharing: an exploratory examination," Journal of Information Science, vol. 34, no. 5, p. 742, 2008.

[22] H. F. Lin, "Knowledge sharing and firm innovation capability: an empirical study," International Journal of Manpower, vol. 28, no. 3/4, pp. 315-332, 2007.

[23] G. Meirovich, Y. Brender-Ilan, and A. Meirovich, "Quality of hospital service: the impact of formalization and decentralization," International Journal of Health Care Quality Assurance, vol. 20, no. 3, pp. 240-252, 2007.

[24] C. Chen and S. Hung, "To give or to receive? Factors influencing members' knowledge sharing and community promotion in professional virtual communities," Information \& Management, vol. 47, no. 4, pp. 226-236, 2010.

[25] M. R. Lee and Y. C. Lan, "Toward a unified knowledge management model for SMEs," Expert Systems with Applications, vol. 38, no. 1, pp. 729-735, 2011.

[26] J. M. Pawlowski and M. Bick, "The global knowledge management framework: Towards a theory for knowledge management in globally distributed settings," Leading Issues in Knowledge Management, Volume Two, vol. 2, p. 134, 2015. 
[27] Y. C. Lee and S. K. Lee, "Capabilities, processes, and performance of knowledge management: A structural approach," Human Factors and Ergonomics in Manufacturing \& Service Industries, vol. 17, no. 1, pp. 21-41, 2007.

[28] C. Chen and J. Huang, "How organizational climate and structure affect knowledge management--The social interaction perspective," International Journal of Information Management, vol. 27, no. 2, pp. 104-118, 2007.

[29] A. Willem and M. Buelens, "Knowledge sharing in inter-unit cooperative episodes: The impact of organizational structure dimensions," International Journal of Information Management, vol. 29, no. 2, pp. 151-160, 2009.

[30] C. Yang and L. C. Chen, "Can organizational knowledge capabilities affect knowledge sharing behavior?," Journal of Information Science, vol. 33, no. 1, pp. 95-109, 2007.

[31] H. Lin, "A stage model of knowledge management: an empirical investigation of process and effectiveness," Journal of Information Science, vol. 33, no. 6, p. 643, 2007.

[32] J. F. Cohen and K. Olsen, "Knowledge management capabilities and firm performance: A test of universalistic, contingency and complementarity perspectives," Expert Systems with Applications, vol. 42, no. 3, pp. 1178-1188, 2015.

[33] W. Li, "Virtual knowledge sharing in a cross-cultural context," Journal of Knowledge Management, vol. 14, no. 1, pp. 38-50, 2010.

[34] N. Behringer and K. Sassenberg, "Introducing social media for knowledge management: Determinants of employees' intentions to adopt new tools," Computers in Human Behavior, vol. 48, pp. 290-296, 2015.

[35] M. Razi, "Applicability of technology acceptance in knowledge management implementation," in The 6th International Conference on Information Technology (ICIT 2013), Amman, Jordan, 2013.

[36] M. J. M. Razi, A Model of Knowledge Management Readiness And Its Contributing Factors: Measuring organizational members readiness for knowledge management using intention to be involved with SECI processes. Germany: LAP LAMBERT Academic Publishing, 2014, p. 268.

[37] J. Hair, W. Black, B. Babin, and R. Anderson, Multivariate Data Analysis a Global Perspective, Seventh ed. (New Jersey). Pearson Education, 2010.

[38] J. Cohen, P. Cohen, S. G. West, and L. S. Aiken, Applied multiple regression/correlation analysis for the behavioral sciences. Routledge, 2013.

[39] M. J. M. Razi, N. S. A. Karim, and N. Mohamed, "Knowledge management readiness measurement: Case study at institution of higher learning in Malaysia," in 2011 International Conference on Research and Innovation in Information Systems, 2011, pp. 1-5: IEEE.

[40] M. Cimperman, M. M. Brenčič, and P. Trkman, "Analyzing older users' home telehealth services acceptance behavior-applying an Extended UTAUT model," International journal of medical informatics, vol. 90, pp. 22$31,2016$.

[41] M. Kuciapski, "A model of mobile technologies acceptance for knowledge transfer by employees," Journal of Knowledge Management, no. just-accepted, pp. 00-00, 2017.

[42] L. Khanam, M. A. Mahfuz, and E. Ahmed, "Employee Behavioral Intention to Adopt Knowledge Management Systems (KMS) in Bangladesh," in European Conference on Knowledge Management, 2016, p. 445: Academic Conferences International Limited. 


\section{BIOGRAPHIES OF AUTHORS}

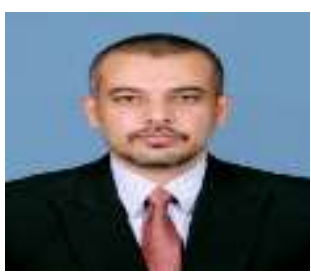

Dr. Mohamed Jalaldeen Mohamed Razi is an Assistant Professor at the Department of Information Systems, International Islamic University Malaysia (IIUM). He obtained his bachelor degree in Commerce (B. Com) and Master degree in Business Administration (MBA) from University of Colombo, Sri Lanka in 1998 and 2003 respectively and his $\mathrm{PhD}$ in Information Technology (PhD in IT) from IIUM in 2011. Currently, his research interests are in Knowledge Management, Electronic Commerce, and IT adoption and appropriation.

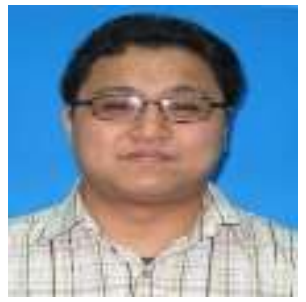

Mohd Izzuddin Mohd Tamrin is a Lecturer in the Department of Information System, International Islamic University Malaysia. In 2004, he received his B.IT. degree majoring in Information System Engineering from Multimedia University Malaysia. One year later, he obtained his M.IT. degree from University of Melbourne Australia. In 2013, he earned his Ph.D. degree from International Islamic University Malaysia. Prior to his academic life, he was employed in IT Department for Telekom Malaysia, one of the biggest telecommunication service providers in Malaysia.

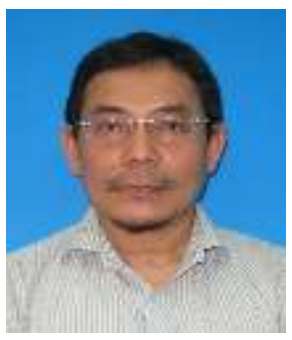

Abdul Rahman Ahmad Dahlan is a Senior Academic Fellow at the Kulliyah of Information and Communication Technology, International Islamic University Malaysia (IIUM). Currently, he is the Deputy Director, Office of Corporate Strategy, IIUM

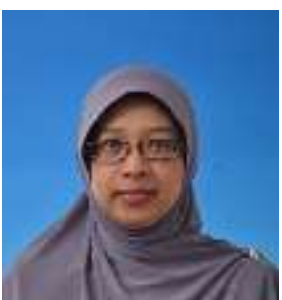

Noor Azian Mohamad Ali is an Academic Fellow at the Department of Information Systems, Kulliyyah of Information and Communication Technology in International Islamic University Malaysia. Prior to being an academic fellow at IIUM, she has worked for Celcom Malaysia and DiGi Telecommunication since 1995 . Now, she is currently teaching project management course and supervising students doing their final year projects. She is also a Project Coordinator at IIUM Advanced Technologies Sdn Bhd overseeing system development and managing client projects. Areas of interest and expertise are in telecommunication, project management, system analysis and design, technopreneurship and startup development. 